\title{
Coral and reef fish community recovery following the 2010 extreme ocean warming event (mass bleaching event) at Thailand
}

\author{
Krisanadej Jaroensutasinee $^{\mathrm{a}}$ (D) $\mid$ Sirirat Somchuea ${ }^{\mathrm{a}}$ | Mullica Jaroensutasinee ${ }^{\text {a* }}$ (iD)
}

Centre of Excellence for Ecoinformatics, School of Science, Walailak University 222 Thaiburi, Thasala, Nakhon Si Thammarat 80161, Thailand.

*Corresponding author: mullica.jn@gmail.com

\begin{abstract}
Reef fish play an important role in the community dynamics of coral reefs and maintaining healthy reefs. This study aimed to (1) assess coral recovery at reefs around Racha Yai Island after the 2010 mass coral bleaching event and (2) compare the fish community indices (Shannon diversity, evenness) and fish trophic functional groups between low (Patok Bay) and high (Khonkae Bay) environmental disturbance sites during 2013-2019. The fish surveys and the percent live coral covers from both bays during 2013-2019 were collected using the fish visual census method and a permanent quadrat method along 50-m transect lines. Our results showed that the percentage of live coral cover at both bays increased by 6 $8 \%$. At Khonkae Bay, there were 69 reef fish species and 10,684 individual fish belonging to 5 orders, with 27 families and 54 genera observed from 7 orders: Perciformes (91.03\%), Tetraodontiformes (5.54\%), Syngnathiformes (1.24\%), Beloniformes (0.26\%), Beryciformes (1.25\%), Scorpaeniformes (0.70\%), and Aulopiformes $(0.06 \%)$. Fish community indices at Khonkae Bay increased during 2013-2019 and were composed of species richness (3.65-10.53), the Shannon index (0.653.49), and species evenness (0.49-0.91). At Patok Bay, there were 60 reef fish species and 10,362 individual fish belonging to 3 orders, with 22 families and 50 genera observed from 4 orders: Perciformes (93.04\%), Tetraodontiformes (5.92\%), Syngnathiformes (0.55\%), and Anguilliformes (0.53\%). Fish community indices at Patok Bay increased during 2014-2019 and were composed of species richness (4.69-8.62), the Shannon index (1.36-3.30), and species evenness (4.92-8.62). Our results suggested that the 2010 mass coral bleaching event had large impacts on both the coral and reef fish community at both low and high environmental disturbance sites with good recovery over nine years.
\end{abstract}

Keywords evenness, fish trophic functional group, Shannon diversity, species richness

\section{Introduction}

Coral reefs are very complex marine ecosystems, where fish diversity is very high (Hermelin-Vivien 1989; Moberg and Folke 1999). Coral reefs host approximately 5,000 marine fish species with an occupying ocean space of less than 0.1\% (Helfman et al 1997). These reefs provide refuge and nursery or settlement habitats for various fish species (Harrington et al 2004; Mumby et al 2004). In the past few decades, live coral has experienced unprecedented loss causing the reef fish species to decline in diversity and abundance. Anthropogenic changes such as ocean acidification, climate change, fishing, nutrient loading, introduced species, disease, and overgrowing tourism especially with diving tourism are the mechanisms responsible for these losses (Fishelson 1995; Rinkevich 1995; Harriott et al 1997; Ehrenfeucht 2014; Boström et al 2018). The reduction of live corals is responsible for the decline of fish species that live and feed on these live corals (Cheal et al 2002; Bellwood et al 2004; Halford et al 2004).

The 2010 mass coral bleaching event was widespread, affecting the degradation of coral reefs within the East Asian Seas Region such as Thailand, Indonesia, Malaysia, Vietnam, and the Philippines (Kimura 2010; Hoeksema and Matthews
2011; Khokiattiwong and Weidong 2012; Sutthacheep et al 2013). Several environmental stresses have been reported to trigger coral bleaching events, e.g., temperature, low salinity, irregularity, chemical toxins, light intensity change, and diseases (Hoegh-Guldberg 2011). The magnitude and frequency of climate-induced coral bleaching are expected to heighten over the coming decades. The Andaman Sea was reported to have an elevated sea surface temperature of between $30-34{ }^{\circ} \mathrm{C}$ during April-June 2010 , causing a severe coral bleaching event where over $50-90 \%$ of the coral was bleached (Chavanich et al 2012; Yeemin et al 2012; Sutthacheep et al 2013). Many studies reported that branching coral species (e.g., Montipora spp., Acropora spp., and Pocillopora spp.) were the most susceptible to bleachinginduced mortality, while massive and encrusting coral species (e.g., Porites spp.) were more resistant to bleaching (Yamazato 1981; Fisk and Done 1985; Glynn 1988; Brown and Suharsono 1990; Hoegh-Guldberg and Salvat 1995; Sheppard 1999; McClanahan 2000; Edwards et al 2001).

Coral loss has a significant impact on reef fish abundance and diversity (Graham et al 2006, 2008). The Andaman Sea is characterized by its high fish diversity and endemic fish species (Randall 1998; Randall and Satapoomin 
1999), but information on how coral loss due to mass bleaching events affects reef fish diversity is very limited in this area (Satapoomin 2011; Noosang et al 2016). Species richness and abundance of reef fish caused by coral reef decline are still uncertain (McClanahan and Arthur 2001; Smith 2007). To the best of our knowledge, this study is among the first to investigate how reef fish diversity and their trophic functional groups recovered during 2013-2019 after the 2010 mass bleaching event in Southern Thailand.

This study addressed the following questions: (1) How to live coral cover at Racha Yai Island has recovered after the 2010 mass coral bleaching event, and (2) How to fish communities have changed as a function of environmental disturbances at Racha Yai Island. To investigate, we compared (1) the percentage of live coral cover and (2) fish diversity and fish feeding habit between low and high environmental disturbance sites (i.e. sites affected by the 2010 mass coral bleaching event) at Racha Yai Island during 2013-2019. We expected to find a decline in fish species that rely directly or indirectly on live corals for their diet after the

(a)

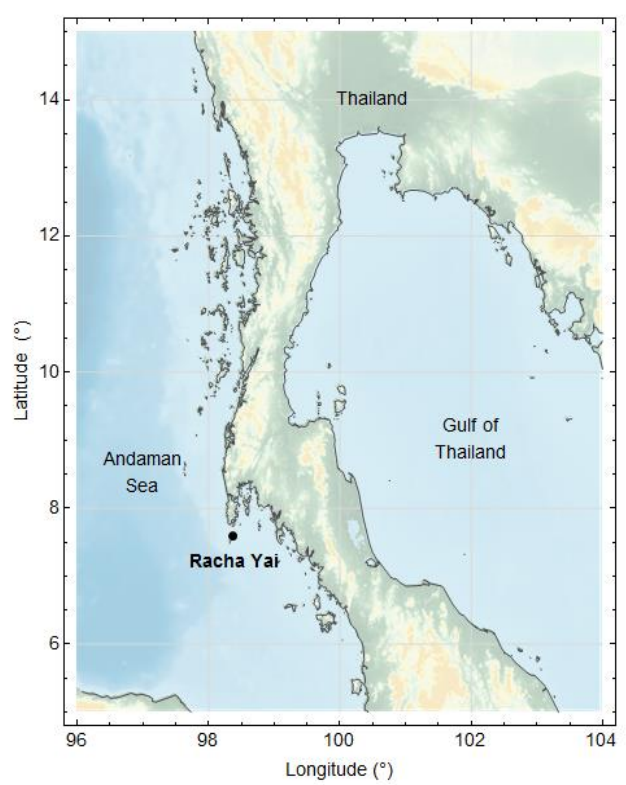

2010 bleaching event, followed by increases in fish diversity and abundance after coral recovery.

\section{Materials and Methods}

\subsection{Study site}

The study was conducted on the reef around Racha Yai Island, Southern Thailand (Figure 1a,b). The study was carried out at two locations: Khonkae Bay (07으'17" N, 9822'35" E) and Patok Bay (0736'34" N, 9821'56" E). Khonkae Bay forms a fringing reef with a depth ranging from 1-12 $\mathrm{m}$ located in a small bay on the eastern side of Racha Yai Island. Patok Bay also forms a fringing reef with a depth ranging from 5-18 m located on the western side of Racha Yai Island. The 2010 mass coral bleaching event affected the reefs around Racha Yai Island. The reef at Khonkae Bay was heavily damaged with a $90 \%$ loss of live coral, but the reef at Patok Bay was affected less by the bleaching event with a $10 \%$ loss of live coral (per. obs.).

(b)

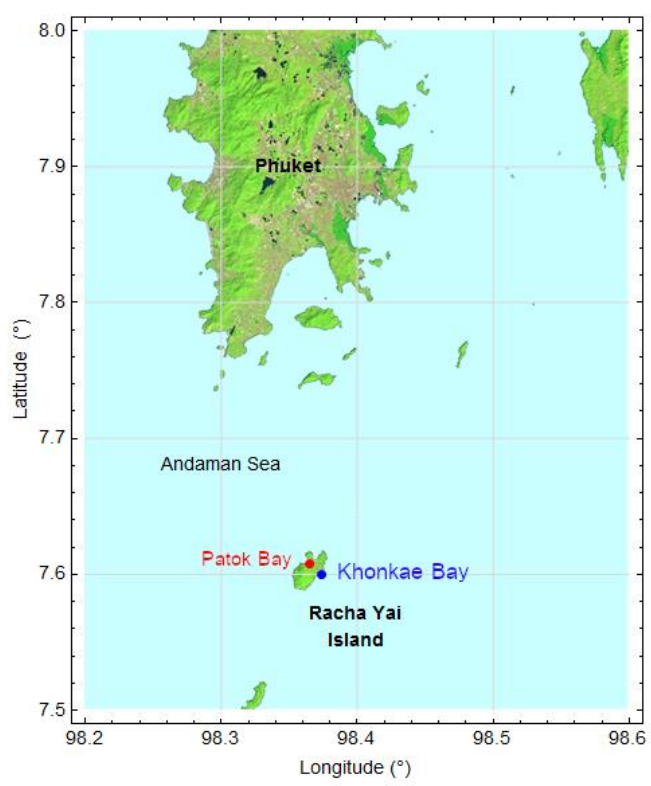

Figure 1 Map of study sites. (a) Map of Racha Yai, Southern Thailand, and (b) Location of Patok Bay and Khonkae Bay at Racha Yai Island, Thailand.

\subsection{Data collection}

The fish surveys from both Khonkae and Patok Bays were collected at the same time of day in NovemberDecember during 2013-2019 using the fish visual census method along 50-m transect lines (English et al 1997; Wismer et al 2014; Triki et al 2018; Triki and Bshary 2019). We set three permanent transect lines parallel to the reef slope at 8$12 \mathrm{~m}$ in depth at Patok Bay, and four permanent transect lines at $10 \mathrm{~m}$ in depth at Khonkae Bay. Each census area covered $250 \mathrm{~m}^{2}$ extending $2.5 \mathrm{~m}$ at both the right and left hands side of a 50-m transect line, and the total coverage census areas with three replicates for Patok Bay and four replicates for Khonkae Bay were $750 \mathrm{~m}^{2}$ and $1000 \mathrm{~m}^{2}$, respectively. Each transect line was $10 \mathrm{~m}$ apart from each other. We identified and counted all reef fish in each transect line at both bays based on several fish identification books, e.g., Allen (2000), and Lieske and Mayer (2001). Each fish species was categorized into one of seven trophic functional groups based on diet and habitat use (i.e., carnivore, corallivore, herbivore, invertebrate consumer, omnivore, piscivore, and planktivore; Table 1) (Durville et al 2003; Randall 2005; Froese and Pauly 2012).

In this study, we used the same three permanent transect lines at Patok Bay and four permanent transect lines at Khonkae Bay to monitor changes in the percent of live coral cover with a permanent quadrat method (English et al 1997). 
We took underwater photographs of $50 \times 50 \mathrm{~cm}^{2}$ quadrat at the 2-m interval with a total of 25 photographs per $50-\mathrm{m}$ transect line to estimate the percentage of live coral cover in each transect line. The photographs were analyzed using CPCe software developed by the National Coral Reef Institute (Kohler and Gill 2006). Percent benthic cover in each quadrat was estimated from 200 randomly distributed points using CPCe software with quadrat data pooled for each transect and averaged across transects at each measurement period. We categorized the benthic cover into four main groups: (1) live coral; (2) dead coral; (3) pavement, rubble, and sand; and (4) others.

Table 1 Number of fish species, fish families, orders, percentage of fish families, and percentage of live coral cover at Khonkae Bay during 2013-2019 and at Patok Bay during 2014-2019.

\begin{tabular}{|c|c|c|c|c|c|c|c|c|c|c|c|c|c|}
\hline \multirow{2}{*}{$\begin{array}{l}\text { Fish and Coral } \\
\text { Parameters (\%) }\end{array}$} & \multicolumn{7}{|c|}{ Khonkae Bay } & \multicolumn{6}{|c|}{ Patok Bay } \\
\hline & 2013 & 2014 & 2015 & 2016 & 2017 & 2018 & 2019 & 2014 & 2015 & 2016 & 2017 & 2018 & 2019 \\
\hline \multicolumn{14}{|l|}{ Fish family } \\
\hline Perciformes & 95.31 & 89.39 & 90.61 & 88.76 & 91.26 & 91.15 & 90.70 & 88.89 & 92.42 & 93.67 & 94.79 & 94.85 & 94.90 \\
\hline Tetraodontiformes & 1.56 & 4.58 & 4.92 & 8.99 & 5.83 & 6.19 & 6.70 & 6.35 & 7.58 & 5.06 & 5.21 & 5.15 & 2.00 \\
\hline Syngnathiformes & 1.56 & 1.52 & 1.64 & 1.12 & 0.97 & 0.88 & 1.00 & - & - & 1.27 & - & - & 3.10 \\
\hline Beloniformes & - & - & - & - & 0.97 & 0.88 & - & - & - & - & - & - & - \\
\hline Beryciformes & 1.56 & 3.00 & 3.28 & - & - & - & 0.90 & - & - & - & - & - & - \\
\hline Scorpaeniformes & - & 1.52 & - & 1.12 & 0.97 & 0.88 & 0.40 & - & - & - & - & - & - \\
\hline Anguilliformes & - & - & - & - & - & - & - & 1.59 & - & - & - & - & - \\
\hline Aulopiformes & - & - & - & - & - & - & 0.40 & - & - & - & - & - & - \\
\hline \multicolumn{14}{|l|}{ Coral Cover } \\
\hline Live coral & 13.74 & 14.8 & 15.2 & 15.89 & 15.99 & 20.16 & 22.18 & 21.34 & 22.1 & 23.05 & 24.65 & 26.84 & 27.55 \\
\hline Dead cora & 58.78 & 57.9 & 57.05 & 54.45 & 53.58 & 50.33 & 50.12 & 40.17 & 37.55 & 39.05 & 35.38 & 34.79 & 33.85 \\
\hline $\begin{array}{l}\text { Pavement, rubble } \\
\text { and sand }\end{array}$ & 22.26 & 21.7 & 21.85 & 22.1 & 22.3 & 20.98 & 32.25 & 30.1 & 36.23 & 32.28 & 33.41 & 33.25 & 32.26 \\
\hline Other & 5.22 & 5.6 & 5.9 & 7.56 & 8.13 & 8.53 & 7.74 & 8.39 & 4.12 & 5.62 & 6.56 & 5.12 & 6.34 \\
\hline
\end{tabular}

\subsection{Data analysis}

The Shannon index, $H=-\Sigma P i$ In Pi (Shannon and Weaver 1949); Margalef's richness index, $D=(s-1) / \ln N$ (Margalef 1968), and Pielou's evenness index, $e=H /$ In $S$ (Pielou 1966) were used to measure the fish diversity. $H$ was the diversity index. Pi was the relative abundance $(S / N)$. D was the richness index. $S$ was the number of individual fish for each species. $N$ was the total number of fish per transect line. $e$ was the evenness index. In was the natural logarithm. $S$ was the total number of species. Parametric statistics were used when normality or other assumptions of parametric tests were met. Two-way ANOVA tests with posthoc Bonferroni adjustment were used to test the effects of bays, fish trophic functional groups (i.e., carnivore, corallivore, herbivore, invertebrate consumer, omnivore, piscivore, and planktivore), and their interactions on bays and fish trophic functional groups. Linear regression analyses between the number of coral reef fish, number of fish species, Shannon diversity $(H)$, species richness $(D)$, evenness $(e)$, and fish feeding habits and years were tested. All tests were twotailed with a signification level of $P<0.05$.

\section{Results}

\subsection{Live coral cover}

The percentage of live coral at both Khonkae and Patok Bays was positively associated with the years during 2013-2019 and 2014-2019, respectively (Linear regression: Khonkae Bay: $R^{2}=0.841, F_{1,5}=26.390, Y_{\mathrm{KK}}=0.639 \mathrm{x}+$ 2005.229, $P<0.005$, Figure 2a; Patok Bay: $R^{2}=0.972, F_{1,4}=$ 138.596, $\mathrm{Y}_{\mathrm{PT}}=0.726 \mathrm{x}+1998.896, P<0.001$, Figure $\left.2 b\right)$.

\subsection{Fish diversity during 2013-2019}

At Khonkae Bay during 2013-2019, there were 69 reef fish species and 10,684 individual fish belonging to 5 orders, with 27 families and 54 genera observed (Table 1). There were reef fish from seven orders: Perciformes (91.03\%), Tetraodontiformes (5.54\%), Syngnathiformes (1.24\%), Beloniformes (0.26\%), Beryciformes (1.25\%), Scorpaeniformes $(0.70 \%)$, and Aulopiformes $(0.06 \%)$ (Table 1). The list of families that had the top three species composition in the coral reef areas included Pomacentridae, Labridae, and Serranidae (Table 1$)$. The species richness $\left(D_{\mathrm{KK}}\right)$ ranged from 3.65 to 10.53 . The Shannon index $\left(H_{\mathrm{KK}}\right)$ ranged from 0.65 to 3.49 . The species evenness $\left(e_{\mathrm{KK}}\right)$ ranged from 0.49 to 0.91 . The number of fish species, species richness, Shannon index, and species evenness were positively 
associated with the years during 2013-2019 (Linear regression: the number of fish species: $R^{2}=0.890, F_{1,26}=$ 209.493, $Y_{\mathrm{KK}}=0.147 \mathrm{x}+2009.694, P<0.001$, Figure 3a; the species richness: $R^{2}=0.858, F_{1,26}=156.965, Y_{\mathrm{KK}}=0.877 \mathrm{x}+$ 2009.681, $P<0.001$, Figure 3c; the Shannon index: $R^{2}=0.583$,
$F_{1,26}=36.402, \mathrm{Y}_{\mathrm{KK}}=1.860 \mathrm{x}+2011.673, P<0.001$, Figure 3e; and the species evenness: $R^{2}=0.388, F_{1,26}=18.140, \mathrm{Y}_{\mathrm{KK}}=$ 6.923x $+2011.806, P<0.001$, Figure 3g). Otherwise, the number of individual fish was not associated with the years during 2013-2019 $\left(F_{1,26}=0.112, n s\right)$.

(a)

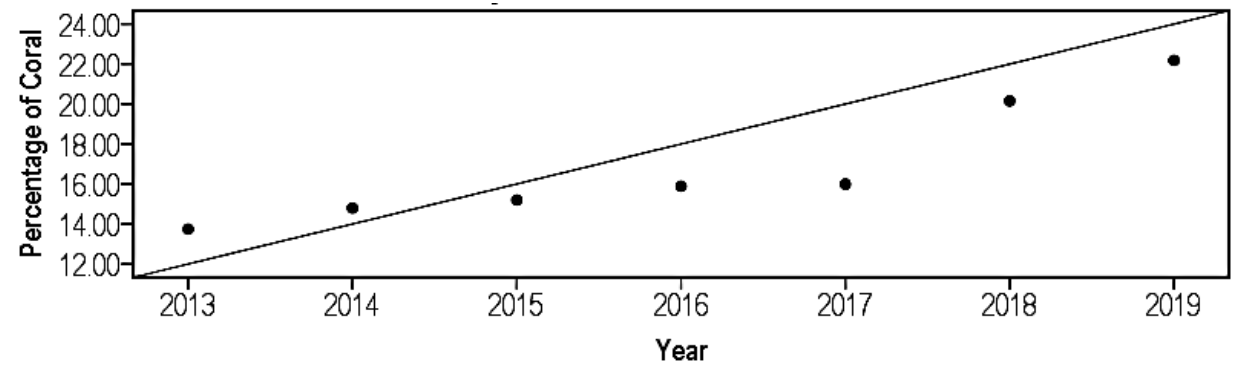

(b)

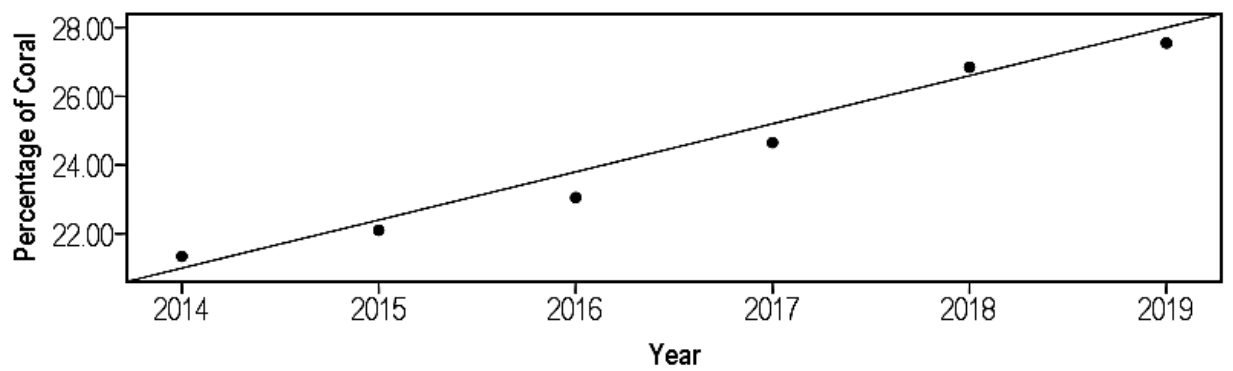

Figure 2 Percentage of live coral cover at two study sites at Racha Yai Island, Southern Thailand. (a) Khonkae Bay during 2013-2019, and (b) Patok Bay during 2014-2019.

At Patok Bay, during 2014-2019, there were 60 reef fish species and 10,362 individual fish belonging to 3 orders, with 22 families and 50 genera observed. There were reef fish from four orders: Perciformes (93.04\%), Tetraodontiformes (5.92\%), Syngnathiformes $(0.55 \%)$, and Anguilliformes $(0.53 \%)$. The list of families that had the three top species composition in the coral reef areas included Pomacentridae, Labridae, and Chaetodontidae. The species richness $\left(D_{\mathrm{PT}}\right)$ ranged from 4.69 to 8.62 . The Shannon index $\left(H_{\mathrm{PT}}\right)$ ranged from 1.36 to 3.30 . The species evenness $\left(e_{\mathrm{PT}}\right)$ ranged from 4.92 to 8.62. The number of fish species, species richness, and number of individual fish were positively associated with the years during 2014-2019 (Linear regression: the number of fish species: $R^{2}=0.880, F_{1,16}=117.045, \mathrm{Y}_{\mathrm{PT}}=0.131 \mathrm{x}+2010.976, P$ $<0.001$, Figure $3 \mathrm{~b}$; the species richness: $R^{2}=0.479, F_{1,16}=$ 14.682, $Y_{\mathrm{PT}}=0.918 \mathrm{x}+2010.275, P<0.001$, Figure $3 d$; and the number of individual fish $R^{2}=0.882, F_{1,16}=119.774, Y_{\mathrm{PT}}=$ $0.004 x+2013.956, P<0.001$, Figure 3j). The Shannon index and species evenness were not associated with the years during 2014-2019 (the Shannon index: $F_{1,16}=0.003, n s$, and the species evenness: $F_{1,16}=0.2111, n s$; Figure $3 f, h$ ).

\subsection{Fish feeding habits}

There were seven trophic functional groups present at both bays: omnivores ( $\bar{x} \pm$ SD: $248.17 \pm 206.14)$, planktivores $(\bar{x} \pm S D: 132.57 \pm 90.46)$, carnivores ( $\bar{x} \pm S D: 66.85 \pm 81.77)$, herbivores ( $\bar{x} \pm S D$ : $60.45 \pm 42.28$ ), invertebrate consumer $(\bar{x} \pm$ SD: $15.76 \pm 8.61)$, corallivores $(\bar{x} \pm$ SD: $10.17 \pm 8.40)$, and piscivores ( $\bar{x} \pm S D: 2.00 \pm 2.08$ ). Comparing the number of fish among the trophic functional groups at both bays, Patok Bay $(\bar{x} \pm$ SD: $99.39 \pm 129.88)$ had a higher number of fish than Khonkae Bay ( $\bar{x} \pm$ SD: $57.15 \pm 111.22$ ), and the number of fish differed among the trophic functional groups with some interaction between bays and trophic functional groups (Two-way ANOVA: bays: $F_{1,292}=15.123, P<0.001$; trophic functional groups: $F_{6,292}=44.790, P<0.001$; interaction: $F_{6,292}$ $=3.895, P<0.005$; Table 2). Bonferroni's posthoc tests showed that Patok Bay had a higher number of corallivores, planktivores, and carnivores than Khonkae Bay, but there were no differences in the number of piscivores, herbivores, omnivores, and invertebrate consumers between both bays (Table 2).

At Khonkae Bay, the number of piscivore, corallivore, and invertebrate consumer fish were positively associated with the years during 2013-2019 (Linear regression: Piscivore: $R^{2}=0.546, F_{1,26}=10.842, \mathrm{Y}_{\mathrm{PCV}}=0.804 \mathrm{x}+2014.794$, $P<0.05$, Figure 4a; Corallivore: $R^{2}=0.546, F_{1,26}=31.291, Y_{\mathrm{CLV}}$ $=0.416 \mathrm{x}+2013.399, P<0.001$, Figure $4 \mathrm{c}$; and Invertebrate Consumer: $R^{2}=0.270, F_{1,26}=9.630, Y_{C L V}=0.139 x+2014.195$, $P<0.05$, Figure $4 \mathrm{~m})$. Otherwise, the number of planktivore, carnivore, herbivore, and omnivore fish were not associated with the years during 2013-2019 (Planktivore: $F_{1,26}=0.552$, $n s$, Carnivore: $F_{1,26}=2.474, n s$, Herbivore: $F_{1,26}=2.159, n s$, and Omnivore: $F_{1,26}=0.001, n s$; Figure $4 \mathrm{e}, \mathrm{g}, \mathrm{i}, \mathrm{k}$ ). 
Khonkae Bay

(a)

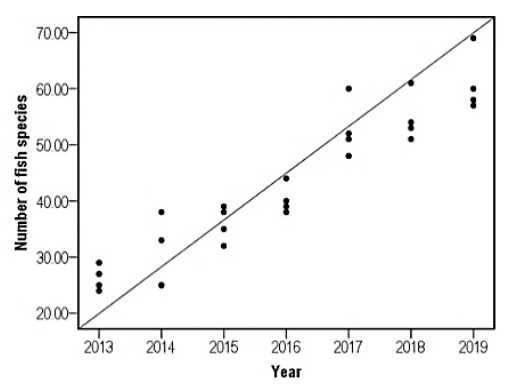

(c)

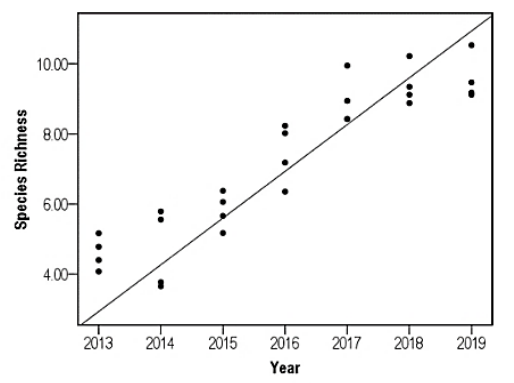

(e)

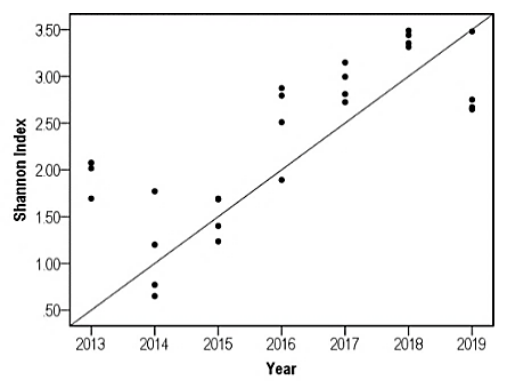

(g)

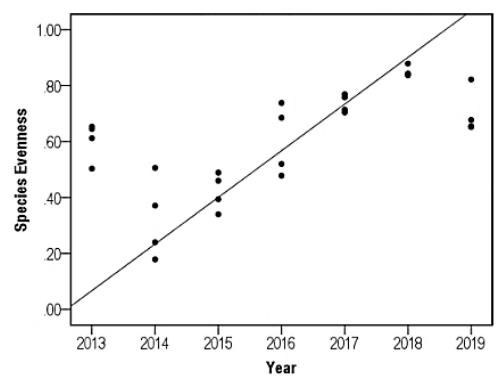

(i)

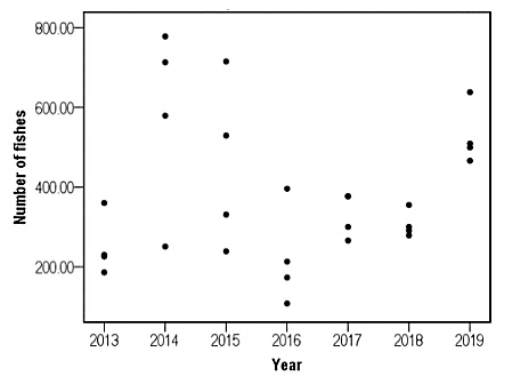

Patok Bay

(b)

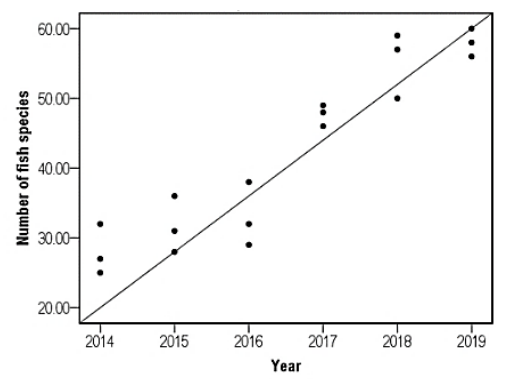

(d)

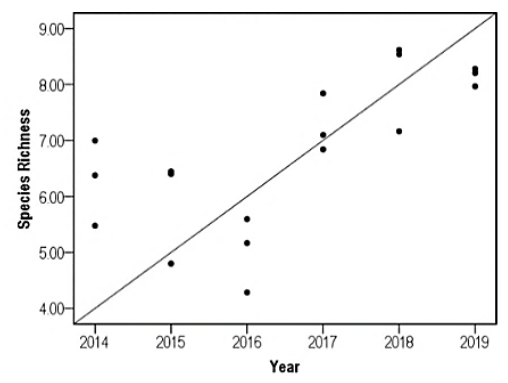

(f)

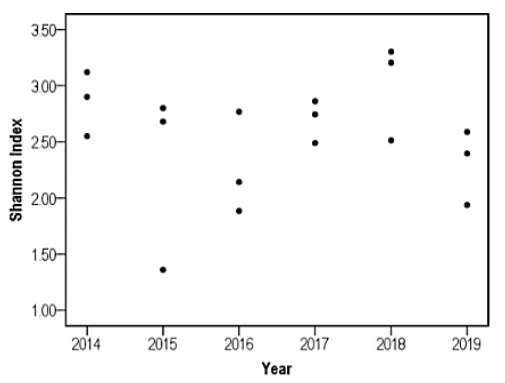

(h)

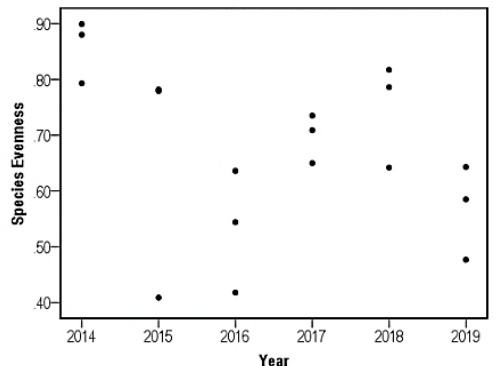

(j)

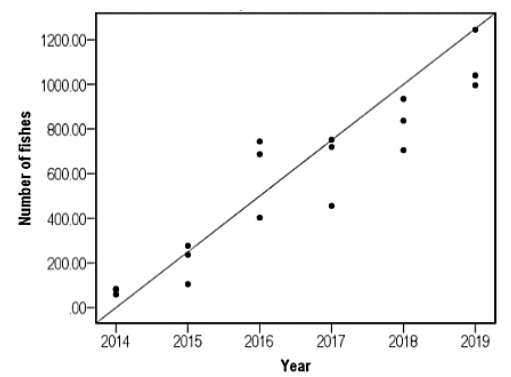

Figure 3 Fish species, diversity, species richness, and evenness at Khonkae Bay during 2013-2019 and at Patok Bay during 2014-2019. (a-b) Number of fish species, (c-d) species richness, (e-f) Shannon index, ( $g-h)$ species evenness, and (i-j) number of individual fish.

At Patok Bay, the number of piscivore, corallivore, planktivore, carnivore, herbivore, omnivore, and invertebrate consumer fish were positively associated with the years during 2013-2019 (Linear regression: Piscivore: $R^{2}=$ $0.699, F_{1,16}=37.1,7 Y_{\mathrm{PCV}}=0.789 \mathrm{x}+2014.878, P<0.001$, Figure 4b; Corallivore: $R^{2}=0.695, F_{1,16}=36.409, Y_{\mathrm{CLV}}=0.146 \mathrm{x}+$ 
2014.340, $P<0.001$, Figure 4d; Planktivore: $R^{2}=0.633, F_{1,16}=$ 27.619, $\mathrm{Y}_{\mathrm{PV}}=0.018 \mathrm{x}+2013.549, P<0.001$, Figure 4f; Carnivore: $R^{2}=0.693, F_{1,16}=36.150, Y_{\mathrm{CV}}=0.017 \mathrm{x}+2014.676$, $P<0.001$, Figure 4h; Herbivore: $R^{2}=0.756, F_{1,16}=49.504, \mathrm{Y}_{\mathrm{HV}}$
$=0.037 \mathrm{x}+2014.095, P<0.001$, Figure 4j; Omnivore: $R^{2}=$ 0.926, $F_{1,16}=200.857, Y_{\text {ov }}=0.11 \mathrm{x}+2014.329, P<0.001$, Figure 4I; and Invertebrate Consumer: $R^{2}=0.477, F_{1,16}=$ 14.608, $Y_{I C}=0.155 x+2014.492, P<0.05$, Figure $\left.4 n\right)$.

Table 2 Mean \pm SD of the number of fish in seven trophic functional groups at Khonkae Bay and Patok Bay, Southern Thailand.

\begin{tabular}{lcc}
\hline Trophic functional group & Khonkae Bay & Patok Bay \\
\hline Piscivores & $2.00 \pm 2.19^{\mathrm{a}}$ & $2.00 \pm 1.94^{\mathrm{a}}$ \\
Corallivores & $6.86 \pm 5.13^{\mathrm{a}}$ & $15.33 \pm 9.94^{\mathrm{b}}$ \\
Invertebrate consumer & $14.71 \pm 8.48^{\mathrm{a}}$ & $17.17 \pm 8.82^{\mathrm{a}}$ \\
Herbivores & $54.96 \pm 43.32^{\mathrm{a}}$ & $66.83 \pm 41.07^{\mathrm{a}}$ \\
Carnivores & $26.79 \pm 15.56^{\mathrm{a}}$ & $129.17 \pm 102.75^{\mathrm{b}}$ \\
Planktivores & $78.42 \pm 54.41^{\mathrm{a}}$ & $204.78 \pm 77.89^{\mathrm{b}}$ \\
Omnivores & $238.96 \pm 215.14^{\mathrm{a}}$ & $260.44 \pm 198.95^{\mathrm{a}}$ \\
\hline
\end{tabular}

Letters at the mean \pm SD indicate the results of pairwise comparisons among treatments using posthoc tests with Bonferroni adjustment (matching letters indicate a $P$-value $>0.05$ ).

\section{Discussion}

\subsection{Live coral cover}

The 2010 extreme ocean warming event as high as 34 ${ }^{\circ} \mathrm{C}$ has been reported to trigger a mass coral bleaching event in Thailand (Krishnan et al 2011). The effects of this mass bleaching event caused scleractinian corals ranging from reduced growth rates to total morality (Alemu and Clement 2014). The response varied between $90 \%$ mortality in Acropora spp. and Pacillopora spp. to high survival rate in Porites spp. (Chavanich et al 2012; Yeemin et al 2012). Our results showed that the percent live coral reef cover at Patok and Khonkae Bays increased by $6 \%$ and $8 \%$, respectively. Many studies reported that after the 2010 mass coral bleaching event, the percent of live coral reef cover increased by $6-10 \%$ in many reefs, e.g., reefs in the Caribbean increased by $10 \%$ (Perry et al 2013), reefs in Hawaii increased by $9 \%$ (Graham and Nash 2013), the Great Barrier Reef increased by 6-7\% (Osborne et al 2011; Lukoschek et al 2013), reefs in Northwestern Australia increased by $9 \%$ (Gilmour et al 2013), reefs in Samoa increased by 6\% (Houk et al 2010), reefs in the Maldives increased by $7 \%$ (Morri et al 2013), and reefs in the South Andaman Islands increased by $8 \%$ (Marimuthu et al 2013). Gilmour et al (2013) reported that the isolated reef showed rapid recovery of coral cover following a mass bleaching event with the recruit from local sources. These increases in the percent of live coral cover could be due to the high supply of planulae from healthy local reef recruitment. At both bays, the local recruitment of coral larvae from surviving individual corals in deeper or adjacent areas might be very high.

The majority of coral reef lost or recovery is focusing on the percentage of live coral cover of key reef species such as Acropora spp. and Montipora spp. (e.g., Acropora palmata and Acropora cervicornis in the Caribbean (Polidoro and Carpenter 2013); Acropora aspera, Acropora cerealis, Acropora humilis, and Montipora spp. in the South Andaman
Islands (Marimuthu et al 2013); Acropora spp. in the Maldives (Morri et al 2015); Acropora spp. and Montipora spp. in Samoa (Houk et al 2010); and Acropora spp. in the Great Barrier Reef (Lukoschek et al 2013)). In our study, the key coral species with a high percentage of live coral recovery at both bays were Acropora spp. and Montipora spp. as well. Previous studies reported that the growth of live Acropora spp. has a rapid growth rate ranging between $1-12 \mathrm{~cm}$ per year depending on the location, e.g., the growth rate of 1-2 $\mathrm{cm}$ per year in the Indian Ocean (Phanor et al 2016), the growth rate of 1-2 cm per year in Japan (Omori et al 2016), and the growth rate of $1-3 \mathrm{~cm}$ per year in the South Andaman Islands (Morri et al 2015).

During the bleaching event of April-June 2010 in the Andaman Sea, high sea surface temperature (SST) ranging from 30.0 to $34.0{ }^{\circ} \mathrm{C}$ was recorded (Krishnan et al 2011). Acropora spp. was the most susceptible coral to the bleaching with more than $90 \%$ of them bleached in the Andaman Sea (Chavanich et al 2012; Yeemin et al 2012). Previous studies reported that Acropora spp. bleached at $31.00-31.24{ }^{\circ} \mathrm{C}$ in India (Kumar et al 2017) and at $31.00-35.74{ }^{\circ} \mathrm{C}$ in Indonesia (Johan et al 2012; Wisha and Khoirunnisa 2017). Our results showed that SST at both bays rose from April to May in 2010 from 31.14 to $32.50{ }^{\circ} \mathrm{C}$ (per. obs.), causing Acropora spp. and Montipora spp. to be severely bleached. SST at both bays during 2013-2019 obtained from our CTD sensors deployed at both bays ranged between $29.00-31.00{ }^{\circ} \mathrm{C}$, which was below the critical SST values to trigger severe bleaching events. This resulted in no severe bleaching event that was observed after the 2010 bleaching event at both bays.

Previous studies reported that the loss of coral cover would lead to a reduction in fish density (Jones et al 2004; Russ and Leahy 2017; Pratchett et al 2018) and a decline in fish abundance (Prachett et al 2011; Brandl et al 2016). Our results showed that after the 2010 mass coral bleaching event, the number of fish species, species richness, evenness, 
and fish abundance increased over the years as the coral reef recovered, which was indicated by increases in the percentage of live coral cover during 2013-2019. The reef fish is associated with shapes of coral, types of coral, and structure complexities; and they use coral reefs as shelter,

\section{Khonkae Bay}

(a)

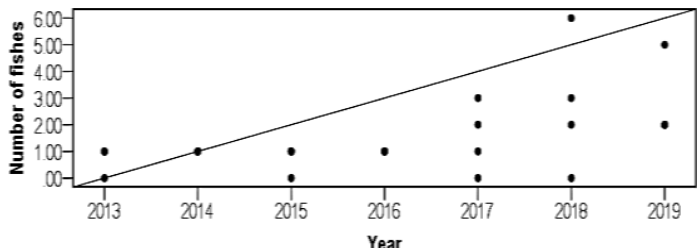

(c)

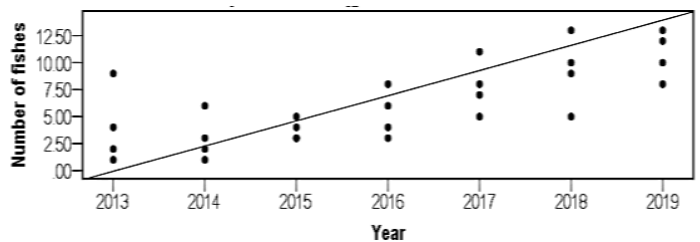

(e)

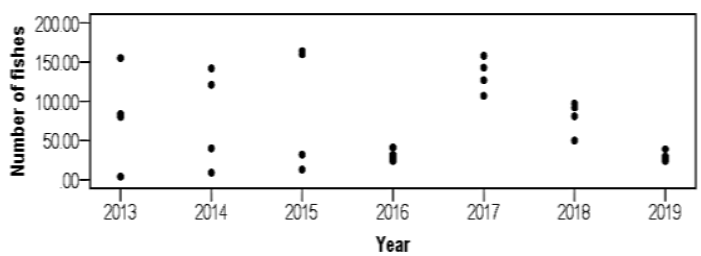

(g)

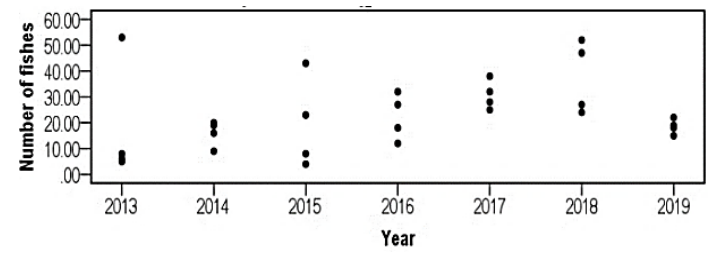

(i)

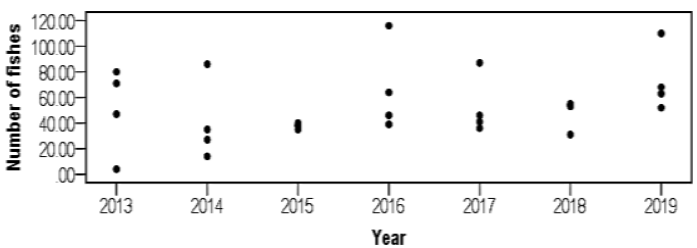

(k)

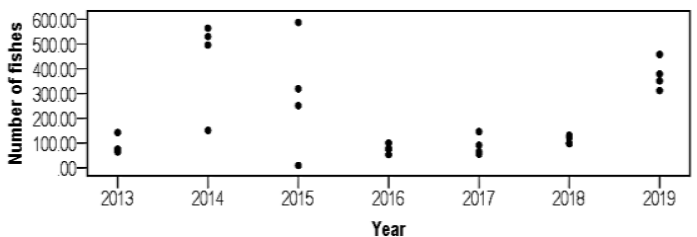

(m)

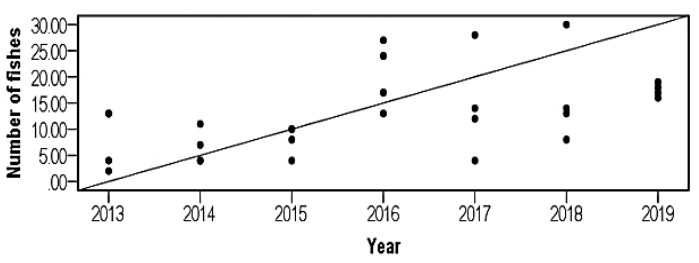

protection, reproduction, and feeding grounds (Reese 1981). Reef fish interact with coral in two modes: direct interaction (e.g., as territory, spawning ground, and foraging grounds) and indirect interaction due to reef structure, hydrology, and sediment (Choat and Bellwood 1991).
Patok Bay

(b)

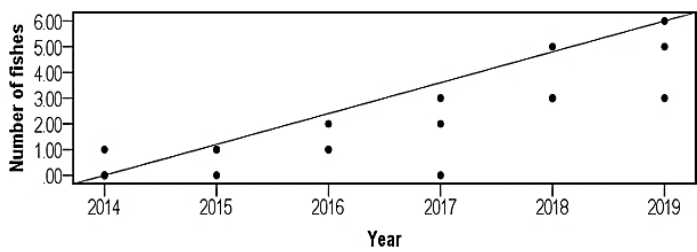

(d)

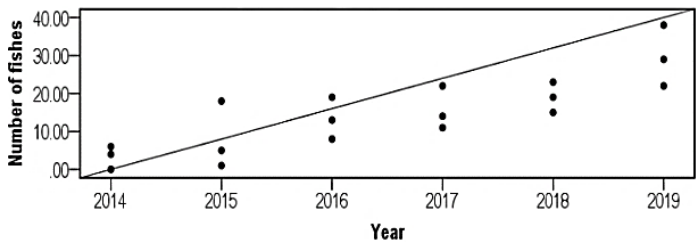

(f)

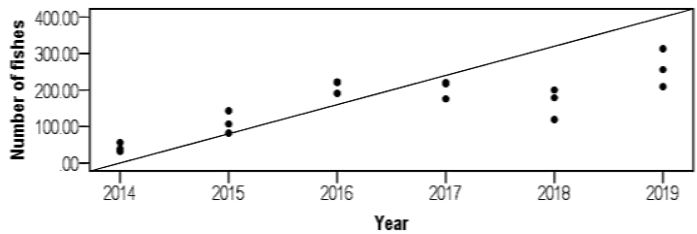

(h)

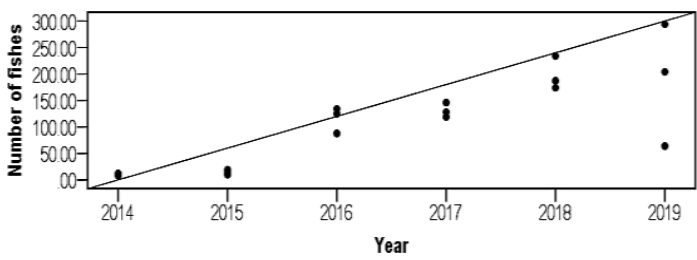

(j)

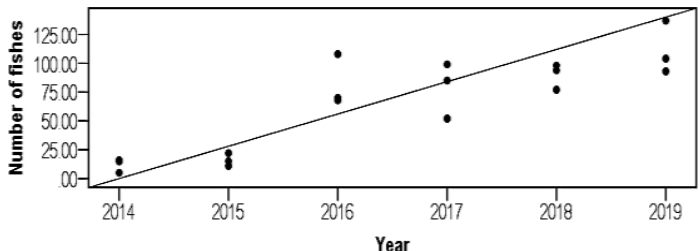

(I)

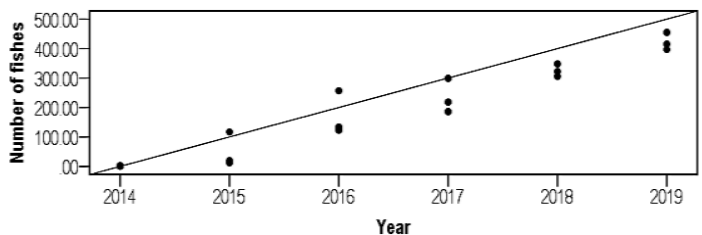

(n)

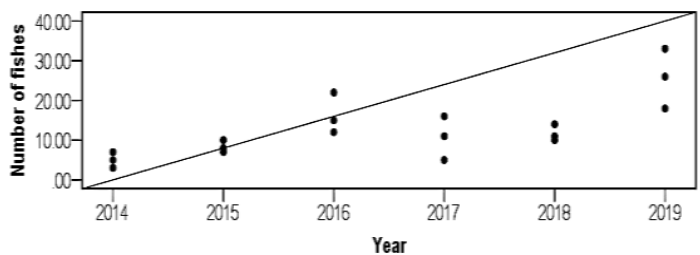

Figure 4 Feeding habits of fish at Khonkae Bay during 2013-2019 and at Patok Bay during 2014-2018. (a-b) Piscivore, (c-d) Corallivore, (e-f) Planktivore, (g-h) Carnivore, (i-j) Herbivore, (k-l) Omnivore, and (m-n) Invertebrate Consumer. 


\subsection{Fish diversity}

A higher Shannon's diversity index is the characteristic of mature and non-perturbed communities, but a lower index is characteristic of constantly changing or newly established communities (Odum 1972). The evenness reflects the abundance distribution between species (Magurran 1988). Our results showed that at Khonkae Bay there were $90 \%$ coral loss due to the 2010 severe bleaching event, where Shannon's diversity and evenness indices were the lowest in 2013 as a new coral community was being established after the $90 \%$ coral loss but showed an increasing trend as the reef was becoming a non-perturbed community for nine years.

\subsection{Fish feeding habits}

Our results indicated that the fish associated with the live coral habitats were from seven reef fish trophic groups at both bays (i.e., piscivore, corallivore, planktivore, carnivore, herbivore, omnivore, and invertebrate consumer). The majority of the reef fish associated with the live coral were omnivores (Pomacentridae and Balistidae families) and planktivores (Acanthuridae, Pomacentridae, and Caesionidae families). Omnivorous fish tend to forage within the live coral areas for two possible reasons: (1) they can seek shelter when predators are present, and (2) high prey concentrations tend to be close to living corals (Hixon and Beets 1993; Wen et al 2012). Our results showed that at both bays the main trophic types were omnivore feeding habit groups that belonged to the Pomacentridae family (e.g., Abudeduf vaigiensis, Abudeduf nototus, Abudeduf sordidus, Pomacetrus lepidogenys, Pomacetrus pavo, Pomacetrus moluccensis, and Neopomacentrus sororius). A majority of the Pomacentridae are small, territorial, and live close to the substratum for shelter. They are influenced mostly by the morphological characteristics of the substratum and use corals more as a habitat or shelter than as a food resource (Prabowo et al 2019). Interestingly, Abudeduf vaigiensis were found in high abundance at Khonkae Bay foraging on bread from tourists. Damselfish in the Pomacentridae family (e.g. Pomacentrus moluccensis, Pomacentrus amboinensis, and Plectroglyphidodon lacrymatus) feed in the water column above branching corals, and when threatened they retreat to within the coral branches for protection (Forrester 1990; Allen 1991). Triggerfish in the Balistidae family (e.g. Balistapus undulates, Melichthys indicus, and Odonus niger) use coral for predator protection and shelter during the day and forage over a large area on the reef at night (Marnane and Bellwood 2002). The presence of reef fish is related to food item abundance (Floeter et al 2007; Prabowo et al 2019). Planktivore fish abundance may also depend on the speed of currents transporting the plankton onto the reef (Thresher 1983).

The corallivore group consisted of reef fish species from the Serranidae, Scaridae, and Chaetodontidae families. The majority of corallivores was coral-feeding fish that had a strong association with live corals. Cole et al (2008) reported that more than $90 \%$ of corallivores target coral prey from the genus Acropora spp. due to their high nitrogen content compared to other corals (Graham 2007). This indicates that corallivores will be strongly affected by the loss of Acropora spp. through habitat and food removal.

Our results showed that the herbivorous fish associated with the live coral at both bays belonged to the Scaridae, Pomacentridae, Labridae, and Siganidae families with a total of 243 species. Herbivorous fish play a vital role in controlling macroalgae in coral reefs and preventing coralalgae phase shift (Bellwood et al 2004), generate greater diversity in benthic communities, and speed up the coral recovery following a coral loss (Cheal et al 2010; Burkepile and Hay 2011). They serve in highly diverse functional roles supported by live corals, such as grazers of algae turfs and macro-algae, scrapers, excavators, and farmers.

Coral structural complexity is important for the existence of small prey fish, concealment from prey when hunting, and protection from potential predators while resting which result in a high abundance in reef-associated predators (Munday and Jones 1998; Graham et al 2007; Wilson et al 2007; Pratchett et al 2011). Piscivores in a reef play a vital role in energy transfer to higher trophic levels and the provision of food and livelihood through fisheries (Hixon 1991; Sadovy 2005). Our results showed that the piscivore reef fish at both bays belonged to the Labridae and Serranidae families, ranging from small (e.g. Epibulus insidiator, Diploprion bifasciatum) to larger-bodied species (e.g. Epinephelus fuscoguttatus, Epinephelus caeruleopunctatus, and Epinephelus malabaricus). Small piscivore fish rely on live coral sheltering within the branches for protection, while larger piscivore fish shelter under larger coral structures (e.g., large coral table form) and depend on the physical structure provided by the coral (Munday et al 2003, Kerry and Bellwood 2012).

\section{Conclusions}

The study observed excellent live coral recovery after the 2010 mass coral bleaching event in Southern Thailand from both low (Patok Bay) and high (Khonkae Bay) environmental disturbance sites during 2013-2019. The number of fish species, species richness, evenness, and fish abundance increased over the years as the coral reef has recovered, indicating that the characteristics of the coral reef were essential in shaping the fish community.

\section{Acknowledgments}

We would like to thank an anonymous reviewer, David Chang, and the referees for comments on previous versions of this manuscript. We are thankful to the fish expert, Mr. Mongkol Klongsamut, and Mr. Sittichai Singhakeaw from the Phuket Marine Biology Center for their great assistance in the field.

\section{Conflict of Interest}

The authors declare that they have no conflict of interest. 


\section{Funding}

This manuscript was funded in part by grants from the NSTDA (Grant No. FDA-CO-2559-2994-TH), Institute of Research and Innovation, WU (Grant No. WU60604), Walailak University Fund (Grant No. 06/2559), and Center of Excellence for Ecoinformatics, Walailak University, for financial support.

\section{References}

Alemu JB, Clement T (2014) Mass coral bleaching in 2010 in the Southern Caribbean. PLOS ONE 9:e92542.

Allen GR (1991) Damselfishes of the world. Mergus Verlag, Melle. Allen GR (2000) Marine fish of South-East Asia. Periplus, Singapore.

Bellwood DR, Hoey AS, Ackerman JL, Depczynski M (2006) Coral bleaching, reef fish community phase shifts and the resilience of coral reefs. Global Change Biology 12:1587-1594.

Bellwood DR, Hughes TP, Folke C, Nyström M (2004) Confronting the coral reef crisis. Nature 429:827-833.

Boström-Einarsson L, Boninl MC, Munday PL, Jones GP (2018) Loss of live coral compromises predator-avoidance behaviour in coral reef damselfish. Scientific Reports 8:7795.

Brandl SJ, Emslie MJ, Ceccarelli DM, Richards TZ (2016) Habitat degradation increases functional originality in highly diverse coral reef fish assemblages. Ecosphere 7:1-19.

Brown BE, Suharsono (1990) Damage and recovery of coral reefs affected by El Niño related seawater warming in the Thousand Islands, Indonesia. Coral Reefs 8:163-170.

Burkepile DE, Hay ME (2011) Feeding complementarity versus redundancy among herbivorous fishes on a Caribbean reef. Coral Reefs 30:351-362.

Chabanet P, Ralambondrainy H, Amanieu M, Faure G, Galzin R (1997) Relationships between coral reef substrata and fish. Coral Reefs. 16:93-102.

Chavanich S, Viyakarn V, Adams P, Klammer J, Cook N (2012) Reef communities after the $\mathbf{2 0 1 0}$ mass coral bleaching at Racha Yai Islamd in the Andaman Sea and Koha in the Gulf of Thailand. Phuket Marine Biological Center Research Bulletin 71:103-110.

Cheal AJ, Coleman G, Delean S, Miller I, Osborne K, Sweatman H (2002) Responses of coral and fish assemblages to a severe but short-lived tropical cyclone on the Great Barrier Reef, Australia. Coral Reefs 21:131-142.

Cheal AJ, Macneli A, Cripps E, Emslie MJ, Jonker M, Schaffelke B, Sweatman H (2010) Coral-macroalgal phase shifts or reef resilience: Links with diversity and functional roles of herbivorous fishes on the Great Barrier Reef. Coral Reefs 29:1005-1015.

Choat JH, Bellwood DR (1991) The Ecology of Fishes on Coral Reefs. Academic Press, Canada.

Cole AJ, Pratchett SM, Jones GP (2008) Diversity and functional importance of coral-feeding fishes on tropical coral reefs. Fish and Fisheries 9:1-22.

Durville P, Chabanet P, Quod PJ (2003) Visual Census of the Reef Fishes in the Natural Reserve of the Glorieuses Islands (Western Indian Ocean). Western Indian Ocean Journal of Marine Science 2:95-104.

Edwards AJ, Clark S, Zahir H, Rajasuriya A, Naseer A, Rubens J (2001) Coral bleaching and mortality on artificial and natural reefs in Maldives in 1998, sea surface temperature anomalies and initial recovery. Marine Pollution Bulletin 42:7-15.

Ehrenfeucht R (2014) Art, public spaces, and private property along the New Orleans. Urban Geography 35:965-979.

English S, Wilkinson C, Baker V (1997) Survey manual for tropical marine resources. $2^{\text {nd }}$ ed. Australian Institute of Marine Science, Australia (AIMS), Townsville.

Fishelson L (1995) Elat (Gulf of Aqaba) littoral: life on the red line of biodegradation, Israel. Journal of Zoology 41:43-55.
Fisk DA, Done TJ (1985) Taxonomic and bathymetric patterns of bleaching in corals, Myrmidon Reef (Queensland). Proceedings of the Fifth International Coral Reef Congress 6:149-154.

Floeter SR, Krohling W, Gasparin JL, Ferriera CEL, Zalmon IR (2007) Reef fish community structure on coastal islands of the south eastern Brazil: the influence of exposure and benthic cover. Environmental Biology of Fish 78:147-160.

Forrester GE (1990) Factors Influencing the Juvenile Demography of a Coral Reef Fish. Ecology 71:1666-1681.

Froese RDP (2012) Fishbase, www.fishbase.org.

Gilmour PJ, Smith DL, Heyward JA, Baird HA, Pratchett SM (2013) Recovery of an Isolated Coral Reef System Following Severe Disturbance. Science 340:69-71.

Glynn PW (1988) El-Niño Southern Oscillation 1982-83 nearshore population, community, and ecosystem response. Annual Review of Ecology, Evolution, and Systematics 19:309-345.

Graham NAJ, McClannahan TR, MacNiel MA, Wilson SK, Polunin NVC Jennings $S$, Chabanet, $P$, Clark S, Spalding MD, Letourneur $Y$, Bigot L, Galzin R, Öhman MC, Garpe KC, Edwards AJ, Sheppard CRC (2008) Climate warning marine protected areas and the ocean-scale integrity of coral reef ecosystems. PloS ONE 3:e3039.

Graham NAJ, Nash KL (2013) The importance of structural complexity in coral reef ecosystems. Coral Reefs 32:315-326.

Graham NAJ, Wilson SK, Jennings S, Polunin NVC, Bijoux JP (2006) Dynamic fragility of oceanic coral reef ecosystems. Proceedings of the National Academy of Sciences of the United States of America 103:8425-8429.

Graham NAJ, Wilson SK, Jennings S, Polunin NVC, Robinson J, Bijoux PJ, Daw TM (2007) Lag Effects in the Impacts of Mass Coral Bleaching on Coral Reef Fish, Fisheries, and Ecosystems. Conservation Biology 21:1291-1300.

Halford A, Cheal AJ, Ryan D, Williams DMcB (2004) Resilience to large-scale disturbance in coral and fish assemblages on the Great Barrier Reef. Ecology 85:1892-1905.

Harmelin-Vivien ML (1989) Implications of feeding specialization on the recruitment processes and community structure of butterflyfishes. Environmental Biology of Fishes 25:101-110.

Harrington L, Fabricius K, De'ath G, Negri AP (2004) Recognition and selection of settlement substrata determine post-settlement survival in corals. Ecology 85:3428-3437.

Harriott VJ, Davis D, Banks SA (1997) Recreational diving and its impact in marine protected areas in Eastern Australia. Journal of the Human Environment 26:173-179.

Helfman GS, Collete BB, Facey DE (1997) The Diversity of Fishes. Blackwell Science, Massachusetts.

Hixon MA (1991) Predation as a process structuring coral reef fish communities. In: Sale PF (ed) The Ecology of Fishes on Coral Reefs, Academic Press, pp 475-508.

Hixon MA, Beets JP (1993) Predation, prey refuges, and the structure of coral-reef fish assemblages. Ecological Monograph 63:77-101.

Hoegh-Guldberg O (2011) The Impact of Climate Change on Coral Reef Ecosystems. Coral Reefs: An Ecosystem in Transition, NY.

Hoegh-Guldberg O, Salvat B (1995) Periodic mass bleaching of reef corals along the outer reef slope in Moorea French Polynesia. Marine Ecology Progress Series 121:181-190.

Hoeksema BW, Matthews JL (2011) Contrasting bleaching patterns in mushroom coral assemblages at Koh Tao, Gulf of Thailand. Coral Reefs 30:95.

Houk P, Musburger C, Wiles P (2010) Water quality and herbivory interactively drive coral-reef recovery patterns in American Samoa. PloS ONE 5:e13913.

Johan O, Bengen GD, Zamani PZ, Suharsono (2012) Distribution and Abundance of Black Band Disease on Corals Montipora sp. in Seribu Islands, Jakarta. Journal of Indonesia Coral Reefs 1:160-170.

Jones GP, McCormick MI, Srinivasan M, Eagle JV (2004) Coral decline threatens fish biodiveristy in marine reserves. Proceedings of the National Academy of Sciences of the United States of America 101:8251-8253. 
Kerry JT, Bellwood DR (2012) The effect of coral morphology on shelter selection by coral reef fishes. Coral Reefs 31:415-424.

Khokiattiwong S, Weidong Y (2012) Note on the occurrence of high sea surface temperature in the Andaman Sea, in 2010. Phuket Marine Biological Center Research Bulletin 71:1-9.

Kimura T (2010) Status of coral reefs in East Asian Seas Region: 2010. Ministry of the Environment of Japan and Japan Wildlife Research Center, Tokyo, Japan.

Kohler EK, Gill MS (2006) Coral point count with Excel extensions (CPCe): A visual basic program for the determination of coral and substrate coverage using random point count methodology. Computers and Geosciences 32:1259-1269.

Krishnan PS, Dam Roy G, George RC, Srivastava, Anand A, Murugesan S, Kaliyamoorthy M, Vikas N, Soundararajan R (2011) Elevated sea surface temperature during May 2010 induces mass bleaching of corals in the Andaman. Current Science 100:111-117.

Lieske E, Mayer R (2001) Reef Fishes of the World: Indo Pacific and Caribbean. Periplus, Singapore.

Lukoschek V, Cross P, Torda G, Zimmerman R, Willis BL (2013) The importance of coral larval recruitment for the recovery of reefs impacted by cyclone Yasi in the Central Great Barrier Reef. PloS ONE 8:e65363.

Magurran A (1988) Ecological Diversity and its Measurement. Princeton, NJ. Margalef R (1968). Diversity and stability: a practical proposal and a model of interdependence. Brookhaven Symposia in Biology 22:25-37.

Marimuthu N, Wilson JJ, Vinithkumar NV, Kirubagaran R (2013) Coral reef recovery status in south Andaman Islands after the bleaching event 2010. Journal of Ocean University of China 1:91-96.

Marnane MJ, Bellwood DR (2002) Diet and nocturnal foraging in cardinalfishes (Apogonidae) at One Tree Reef, Great Barrier Reef, Australia. Marine Ecology Progress Series 231:261-268.

McClanahan TR (2000) Bleaching damage and recovery potential of Maldivian coral reefs. Marine Pollution Bulletin 40:587-597.

McClanahan TR, Arthur R (2001) The effect of marine reserves and habitat on populations of east African coral reef fishes. Ecological Application 11:559-569.

Moberg F, Folke C (1999) Ecological goods and services of coral reef ecosystems. Ecological Economics 29:215-233.

Morri C, Montefalcone M, Lasagna R, Gatti G, Rovere A, Parravicini V, Baldell G, Colantoni P, Bianchi NC (2015) Through bleaching and tsunami: coral reef recovery in the Maldives. Marine Pollution Bulletin 98:188-200.

Morri C, Montefalcone M, Lasagna R, Gatti G, Rovere A, Parravicini V, Baldelli G, Colantoni P, Bianchi CN (2013) Through bleaching and tsunami: Coral reef recovery in the Maldives. Marine Pollution Bulletin 98:188-200.

Mumby PJ, Alasdair Edwards J, Arias-González E, Kenyon LC, Paul BG, Gall A, Malgosia GI, Harborne AR, Claire PL, Renken H, Wabnitz CCC, Llewellyn G (2004) Mangroves enhance the biomass of coral reef fish communities in the Caribbean. Nature 427:533-536.

Munday PL, Jones GP (1998) The ecological implications of small body size among coral-reef fishes. Oceanography and marine biology 36:373-411.

Munday PL, Jones GP, Pratchett MS, Williams AJ (2003) Climate change and the future for coral reef fishes. Fish and Fisheries 9:261-285

Noonsang P, Tina FW, Jaroensutasinee M, Jaroensutasinee $\mathrm{K}$, Chumkiew $\mathrm{S}$, Kuhapong U (2016). Reef Fish Diversity at Racha Yai Island, Thailand. Kasetsart University Fisheries Research Bulletin 40:19-34.

Odum EP (1972). Ecology. 3rd edn. WB Saunders Co., Philadelphia.

Omori M, Higa Y, Shinzato C, Zayasu Y, Nagata T, Nakamura R, Yokokura A, Janadou S (2016) Development of active restoration methodologies for coral reefs using asexual reproduction in Okinawa, Japan, pp. 369-387. In: Proceedings of $13^{\text {th }}$ International Coral Reef Symposium, Honolulu, ICRS2016 Secretaria.

Osborne K, Doliman MA, Burgess CS, Johns AK (2011) Disturbance and the Dynamics of Coral Cover on the Great Barrier Reef (1995-2009). PloS ONE $6 \mathrm{e} 17516$.
Perry CT, Murphy GN, Kench PS, Smithers SG, Edinger EN, Steneck RS Mumby PJ (2013) Caribbean-wide decline in carbonate production threatens coral reef growth. Nature 4:1402.

Phanor M, Kaylee S, April B, Sarah FT (2016) Large-scale coral reef restoration could assist natural recovery in Seychelles, Indian Ocean. Nature Conservation 16:1-17.

Pielou EC (1966) Shannon's formula as a measure of specific diversity: its use and misuse. American Naturalist 100:463-465

Polidoro B, Carpenter K (2013) Dynamics of Coral Reef Recovery. Science 340:34.

Prabowo B, Fahlevy K, Putra FDN, Rizqydiani M, Rahman MKB, Habibie A, Subhan B, Madduppa H (2019) Trophic structure of reef fishes and relationship of corallivore fishes with hard coral in Kepulauan Seribu, Jakarta. IOP Conference Series: Earth and Environmental Science 278: 012059.

Prachett MS, Hoey AS, Wilson SK, Messmer V, Graham NAJ (2011) Changes in biodiversity and functioning of reef fish assemblages following coral bleaching and coral loss. Diversity 3:424-452.

Pratchett MS, Thompson CA, Hoey AS, Cowman PF, Wilson SK (2018) Effects of coral bleaching and coral loss on the structure and function of reef fish assemblages. In: van Oppen MJH, Lough JM (eds) Coral Bleaching: patterns, processes, causes and consequences. Ecological Studies 233, Springer, Switzerland, pp 265-293.

Randall JE (1998) Zoogeography of shore fishes of the Indo-Pacific region. Zoological Studies 37:227-268.

Randall JE (2005) Reef and shore fishes of the South Pacific: New Caledonia to Tahiti and the Pitcairn Islands. University of Hawaii Press, Honolulu.

Randall JR, Satapoomin U (1999) Archamia ataenia, a new species of cardinalfish (Perciformes: Apogonidae) from the Andaman Sea and Mentawai Islands. Phuket Marine Biological Research Center Bulletin 62:1-8.

Reese SE (1981) Predation on coral by fishes of the family Chaetodontidae: implications for conservation and management of coral reef ecosystems. Bulletin Marine Sciences 31:594-604.

Rinkevich B (1995) Restoration strategies for coral reefs damaged by recreational activities: the use of sexual and asexual recruits. Restoration Ecology 3:241-251.

Russ GR, Leahy SM (2017) Rapid decline and decadal-scale recovery of corals and Chaetodon butterflyfish on Philippine coral reefs. Marine Biology 164:29.

Sadovy $Y$ (2015) Trouble on the reef: the imperative for managing vulnerable and valuable fisheries. Fish and Fisheries 6:167-185.

Satapoomin U (2011) The fishes of south western Thailand, the Andaman Sea-a review of research and a provisional checklist of species. Phuket Marine Biological Center, Research Bulletin 70:29-77.

Shannon CE, Weaver W (1949) The Mathematical Theory of Communication. University of Illinois Press, Illinois.

Sheppard C (1999) Coral decline and weather patterns over 20 years in the Chagos Archipelago, Central Indian Ocean. Journal of the Human Environment 28:472-478.

Sutthacheep M, Yucharoen M, Klinthong W, Pengsakun S, Sangmanee K, Yeemin T (2013) Impacts of the 1998 and 2010 mass coral bleaching events on the Western Gulf of Thailand. Deep-Sea Research Part II: Tropical Studies in Oceanography 96:25-31.

Thresher RE (1983) Environmental correlates of the distribution of planktivorous fishes in the One Tree Reef Lagoon. Marine Ecology Progress Series 10:137-145.

Triki Z, Bshary R (2019) Fluctuations in coral reef fish densities after environmental disturbances on the northern Great Barrier Reef. PeerJ 7:e6720.

Triki Z, Wismer S, Levorato E, Bshary R. (2018). A decrease in the abundance and strategic sophistication of cleaner fish after environmental perturbations. Global Change Biology 24:481-489.

Wen CK, Pratchett MS, Almany GR, Jones GP (2012) Patterns of recruitment and microhabitat associations for three predatory coral reef fishes on the southern Great Barrier Reef, Australia. Coral Reefs 32:389-398. 
Wilson SK, Graham NAJ, Polunin NVC (2007) Appraisal of visual assessments of habitat complexity and benthic composition on coral reefs. Marine Biology 151:1069-1076.

Wisha UJ, Khoirunnisa $\mathrm{H}$ (2017) Sea surface temperature rising trend and its influence on the coral mortality in Pagai Strait, Mentawai Islands, Indonesia. Journal of Civil Engineering and Technology 8:725-734.

Wismer S, Pinto Ai, Vail AL, Grutter AS, Bshary R (2014) Variation in cleaner wrasse cooperation and cognition: influence of the developmental environment. Ethology 120:519-531.
Yamazato K (1981) A note on the expulsion of zooxanthallae during summer, 1980 , by the Okinawan reef-building corals. Sesoko Marine Science Laboratory Technical Report 8:9-18.

Yeemin T, Mantachitra V, Plathong S, Nuclear P, Klinthong W, Sutthacheep $M$ (2012) Impacts of coral bleaching, recovery and management in Thailand. Proceedings of the $12^{\text {th }}$ International Coral Reef Symposium, Cairns, Australia, 9-13 July 2010.

Yogesh Kumar JS, Satyanarayana CH, Venkataraman K, Chandra K (2017) Studies on survival and growth rate of transplanted Acroporidae in Gulf of Kachchh Marine National Park, India. Journal of Coastal Conservation 21:2334. 